\title{
Productivity of Cenchrus ciliaris in relation to rain- fall and fertilization
}

\author{
A.S. RAO, K.C. SINGH, AND J.R. WIGHT
}

Authors are Agrometeorologist and Range Mangement Specialist, Central Arid Zone Research Institute, Jodhpur-342, 003, India; and Range Scientist, USDA, Agricultural Research Service, 800 Park Blvd., Boise, Ida. 83712.

\begin{abstract}
Forage for livestock is always in short supply in the arid zone of India. Cenchrus ciliaris $\mathbf{L}$. is one of the major forage grasses cultivated in this region. We studied its productivity in relation to rainfall and nitrogen $(N)$ and phosphorus $(P)$ fertilization in the Indian arid zone at Jodhpur during 1983 to 1992. Factorial combinations of 4 rates of $N\left(0,20,40\right.$, and $\left.60 \mathrm{~kg} \mathrm{ha}^{-1}\right)$ and 3 rates of $P\left(0,15\right.$, and $\left.30 \mathrm{~kg} \mathrm{ha}^{-1}\right)$ were applied annually. Twenty $\mathrm{kg} \mathrm{N}$ $\mathrm{ha}^{-1}$ was the most effective fertilizer treatment, increasing average annual forage yields from 942 to $1,785 \mathrm{~kg} \mathrm{ha}^{-1}$ over the 10 year study with significant yield increases occurring in 7 of the 10 years. Yield responses to $N$ rates greater than $20 \mathrm{~kg} \mathrm{ha}^{-1}$ occurred only during the last 3 years of the study and then only at the $60 \mathrm{~kg} \mathrm{ha}^{-1}$ rate with either 15 or $30 \mathrm{~kg} \mathrm{P} \mathrm{ha}^{-1}$. Yields reached maximum levels on both the nonfertilized and fertilized plots with between 180 and $250 \mathrm{~mm}$ of growing-season rainfall.
\end{abstract}

Key Words: nitrogen, phosphorus, Indian arid zone, forage production

The Indian arid region in Northwest India is characterized by low and variable rainfall. Arable farming is possible in only 1 of every 3 years. Hence, the main economy of this region is dependent on forage production to support its $23 \times 10^{6}$ head of livestock. Several studies have shown that available forage supplies are inadequate to maintain the livestock population in good condition and prevent overuse and degradation of the rangeland. Shankarnarayan et al. (1985) reported that only $44 \%$ of the animals' fodder requirements are met during normal-rainfall years leaving a deficit of 56\%. Ahuja and Mann (1975) estimated a fodder deficit of $35 \%$ based on the land available for grass production. Shankarnarayan and Kalla (1985) estimated the demand for the grazing forage in the northwest arid zone of India was 233 $\times 10^{7} \mathrm{~kg}$ and the supply was only $172 \times 10^{7} \mathrm{~kg}$.

Of the 7 major pasture types available in the Indian arid zone, C. ciliaris is one of the most important grass types. Known locally as Anjan, C. ciliaris is a perennial, nutritious, highly preferred

The authors are thankful to Dr. J. Venkateswarlu, Director, Central Arid Zone Research Institute for his encouragement and the facilities provided. Dr. A.S. Rao thanks the U.S. Department of Agriculture for providing facilities to work at the Northwest Watershed Research Center, Boise, Idaho, during a ICARJUSDAJUSAID Scientist Exchange Program.

Manuscripl accepted 21 May 1995. grass that performs better in low rainfall-conditions than other predominant grasses like Lasiarus sindicus Henr. and $C$. setigerus Vahl. Because of the large deficit of forage supplies, there is considerable need to increase forage production in this arid region. The coarse-textured soils of the Indian arid zone are very low in organic matter content with subsequent deficiences in nitrogen $(\mathrm{N})$ and often other essential plant nutrients. This study was conducted to determine the effects of $\mathrm{N}$ and phosphorus (P) fertilization on the productivity of $C$. ciliaris with varying annual rainfall.

\section{Methods and Procedure}

The study site was located at the Central Arid Zone Research Institute in Jodhpur $\left(26^{\circ} 18^{\prime} \mathrm{N} ; 73^{\circ} 01^{\prime} \mathrm{E}\right.$, elevation above MSL $224 \mathrm{~m}$ ). The average annual rainfall of $360 \mathrm{~mm}$ is highly variable ( coefficient of variation $=60 \%$ ) and usually occurs within a 75 day period (Table 1). Mean annual air temperature is $26.7^{\circ} \mathrm{C}$. The normal crop growing period is between July and September and is dependent on the southwest monsoon rains. Soils at the experimental site are loamy sand, mixed hyperthermic Camborthids low in organic matter $(0.4 \%)$ and have a mechanical composition of 80-90\% sand and $8 \%$ clay. Ficld capacity of the soils is between 0.12 and $0.135 \mathrm{~cm}^{3} \mathrm{~cm}^{-3}$ and wilting point is between 0.055 and $0.065 \mathrm{~cm}^{3} \mathrm{~cm}^{-3}$. Bulk density is 1.12 to $1.56 \mathrm{~g} \mathrm{~cm}^{-3}$, and the hydraulic conductivity is $15 \mathrm{~cm}$ hour ${ }^{-1}$. The soil depth varies between 90 and $100 \mathrm{~cm}$. Olsen extractable soil P (12-15 kg ha-1) and soil $\mathrm{pH}(8.0)$ values from a nearby experiment (Singh and Aggarwal 1988) would be good estimates of the intial values for this experiment. The $12-15 \mathrm{~kg} \mathrm{P} \mathrm{ha} a^{-1}$ test value is considered in the medium range.

Cenchrus ciliaris (c.v. 358) was established on the study site in July 1983. The inter- and intra-row spacings were 75 and $25 \mathrm{~cm}$, respectively. Fertilizer treatments consisted of 4 levels of $N(0$, 20,40 , and $\left.60 \mathrm{~kg} \mathrm{ha}^{-1}\right)$ in combination with 3 levels of $\mathrm{P}(0,15$, and $30 \mathrm{~kg} \mathrm{ha}^{-1}$ ) for a total of 12 treatments. Plot size was $7.5 \mathrm{~m} \times$ $10.0 \mathrm{~m}$. Half of the $\mathrm{N}$ and all of the $P$ of each treatment were side-dressed in deep bands at the time of seeding. The remaining $\mathrm{N}$ was top-dressed one month later following good soaking rains. Fertilization treatments were repeated annually at the onset of the rainy scason. Urea and single superphosphate were the $N$ and $P$ sources, respectively. Treatments were replicated 3 times in a randomized complete block design with a factorial arrangement 
Table 1. Monthly precipitation Jodhpur, India. 1983-1992.

\begin{tabular}{|c|c|c|c|c|c|c|c|c|c|c|c|c|c|c|}
\hline Year & Jan. & Feb. & Mar. & Apr. & May & Jun. & Jul. & Aug. & Sep. & Oct. & Nov. & Dec. & Ann. & $\begin{array}{l}\text { Growing } \\
\text { Season' }\end{array}$ \\
\hline & \multicolumn{14}{|c|}{ 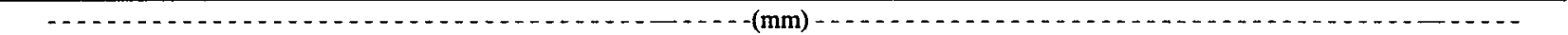 } \\
\hline 1983 & 1 & 1 & 0 & 31 & 38 & 32 & 77 & 88 & 11 & 33 & 0 & 0 & 512 & 409 \\
\hline 1984 & 0 & 0 & 0 & 4 & 0 & 7 & 45 & 86 & 90 & 0 & 0 & 0 & 232 & 219 \\
\hline 1985 & 0 & 0 & 0 & 21 & 41 & 1 & 63 & 72 & 5 & 9 & 0 & 0 & 212 & 152 \\
\hline 1986 & 0 & 1 & 0 & 0 & 55 & 0 & 142 & 42 & 0 & 10 & 0 & 0 & 250 & 183 \\
\hline 1987 & 6 & 6 & 5 & 0 & 28 & 33 & 18 & 14 & 0 & 0 & 0 & 8 & 118 & 70 \\
\hline 1988 & 5 & 0 & 0 & 0 & 0 & 16 & 106 & 96 & 47 & 0 & 0 & 0 & 270 & 257 \\
\hline 1989 & 4 & 0 & 5 & 0 & 0 & 12 & 52 & 139 & 18 & 0 & 0 & 0 & 230 & 210 \\
\hline 1990 & 0 & 36 & 0 & 0 & 31 & 3 & 516 & 180 & 78 & 1 & 0 & 0 & 845 & 775 \\
\hline 1991 & 0 & 0 & 0 & 11 & 0 & 10 & 75 & 96 & 11 & 0 & 0 & 1 & 204 & 193 \\
\hline 1992 & 27 & 0 & 4 & 0 & 5 & 4 & 85 & 101 & 196 & 0 & 0 & 0 & 422 & 393 \\
\hline Mean & 4 & 4 & 2 & 7 & 20 & 12 & 138 & 91 & 46 & 5 & 0 & 0 & 330 & 286 \\
\hline
\end{tabular}

The growing season depends on monsoon rains and usually occurs between July and September.

of treatments. Above-average rainfall resulted in the establishment of a good stand of grass.

All of the forage in each plot was harvested annually when the grass reached maturity. Yields were recorded on an air-dry basis. Percent moisture in air-dry forage in this dry climate is generally lower than the $10-12 \%$ usually reported for air-dry forage in the literature. Analyses of variance were used to evaluate fertilizer treatments on an annual basis and over periods of years. Statistically significant differences in treatment effects were established at $\mathrm{P}_{\leq} 0.05$.

\section{Results and Discussion}

Annual yields of $C$. Ciliaris varied over a wide range during the 10-year study period (Fig. 1). As would be expected, there was a significant year by fertilizer treatment interaction due to the high variation in growing season rainfall. Because of the treatment by year interaction, each year's yield data were analyzed separately (Fig. 1). Combining the low-production years-1985, 1987, and 1989-and the remaining 7 years (high-production years) into 2 separate groups for analyses also eliminated the fertilizer treatment by year interaction and allowed comparison of fertilizer treatments averaged over several years (Fig. 2). For the 3 low-production years, there were no significant yield responses to $\mathrm{N}, \mathrm{P}$, or N-P combinations.

Based on the single-year analyses of variance, there was a significant yield response to $\mathrm{N}$ in all but 3 years of the 10 -year study (Fig. 1). There were only 3 years-1990, 1991 and 1992-in which $\mathrm{N}$ rates greater than $20 \mathrm{~kg} \mathrm{ha}^{-1}$ were measureably effective, and then only at the $60 \mathrm{~kg} \mathrm{~N} \mathrm{ha}^{-1}$ rate applied with P. Phosphorus applied with $\mathrm{N}$ significantly enhanced yields only during the last 3 years of the study suggesting that increased production on the $\mathrm{N}$ fertilized plots the previous years was depleting the reservoir of available soil $P$. Thus to maintain maximum long-term yield responses to $\mathrm{N}$, applications of $\mathbf{P}$ may be necessary. Averaged over the high production years, there was no significant yield response beyond the $20 \mathrm{~kg} \mathrm{~N}^{-1}$ rate (Fig. 2).

Yield responses to $\mathrm{P}$ were inconsistent and difficult to interpret. In 7 of the 10 years, $P$ had no measureable effect on yields. Significant $N$ by P interactions occurred in 1983, 1991, and 1992 and were the result of positive yield responses to $P$ at the 0 and $60 \mathrm{~kg} \mathrm{~N} \mathrm{ha}{ }^{-1}$ rate and negative yield responses to $P$ at the $20 \mathrm{~kg} \mathrm{~N}$ ha ${ }^{-1}$ rate (Fig. 1). The same interactions were evident in the high- production years analysis (Fig. 2). It seems unreasonable that applications of $\mathbf{P}$ fertilizer would actually decrease forage yields when applied with $20 \mathrm{~kg} \mathrm{~N} \mathrm{ha}^{-1}$; have no effect at the $40 \mathrm{~kg} \mathrm{~N} \mathrm{ha}^{-1}$ rate; and have positive effects at the 0 and $60 \mathrm{~kg} \mathrm{~N}^{-1}$ rates. There is no known explanation for this combination of yield responses, especially the yield reductions, unless it is due to a lack of homogeneity in the experimental plots. Such a combination of responses tended to obscure the role of $\mathrm{P}$ in the production of $C$. Ciliaris in this study. However, the response to $\mathrm{P}$ at the high $N$ rate after several years of high productivity does seem logical and to be a true $\mathrm{P}$ effect. In a 4 -year study reported by Wiedenfeld et al. (1985), yield increases on the fertilized plots
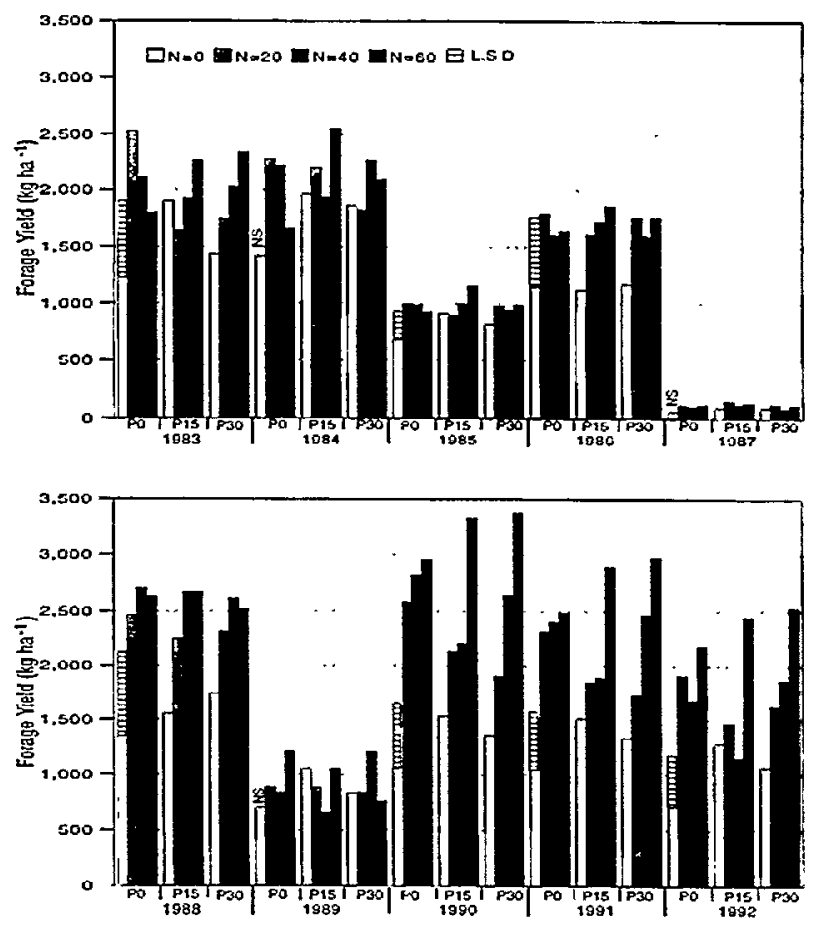

YEAR AND P APPLICATIONRATES

Fig. 1. The effect of nitrogen and phosphorus fertilization on forage yields of $C$. ciliaris. Jodhpur, India. 1983-1992. (L.S.D.'s can be used for within year comparisons among all 12 fertilization treatments.) 


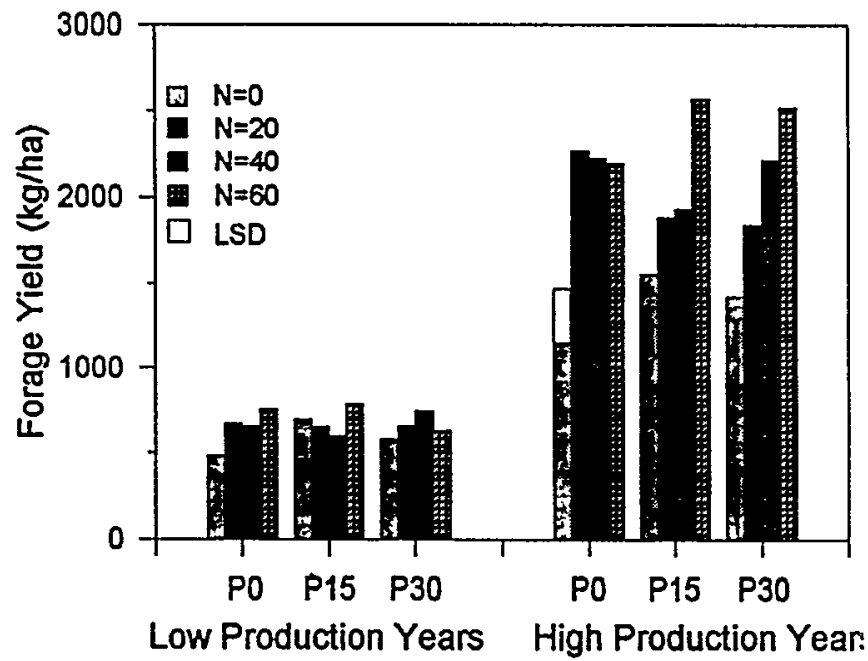

Fig. 2. The effect of nitrogen and phosphorus fertilization on forage yields of $C$. ciliaris averaged over the three low-production years and the seven high-production years. Jodhpur, India. 1983-1992.

were due primarily to $\mathrm{N}$ with some additional response to $\mathrm{P}$ only at the high $\mathrm{N}$ rates during 2 of 4 years.

There was no significant correlation between yield and growing-season rainfall (Fig. 3). No measurable yield increases occurred with additions of rainfall above $250 \mathrm{~mm}$. Distribution of rainfall during the growing-season also affected plant response, thus further affecting the correlation between growing-season or annual rainfall and forage yields.

Forage yields of both the nonfertilized and fertilized plots tended to reach maximum levels with between 180 and $250 \mathrm{~mm}$ of growing season rainfall suggesting that $C$. Ciliaris reaches its genetic productivity potential at these rainfall levels. On a site near Kingsville, Tex. with an average annual precipitation of 640 $\mathrm{mm}$, maximum, single-harvest annual yields of $C$. Ciliaris on plots receiving 156 and 44 or more $\mathrm{kg} \mathrm{ha}^{-1} \mathrm{~N}$ and $\mathrm{P}$, respectively, were maximized near $3000 \mathrm{~kg} \mathrm{ha}^{-1}$ (Mutz and Drawe 1983), about the same as the maximum yields in this study.

It is significant to note that maximum yield responses to $\mathrm{N}$ fertilization occurred with between 180 and $250 \mathrm{~mm}$ of growingseason rainfall. For this 10 -year study, the growing- season rainfall represented $86 \%$ of the total annual rainfall. Using this relationship between growing-season and annual rainfall, the longterm growing-season rainfall for this location would be $0.86 \times$ 360 or $311 \mathrm{~mm}$. Assuming a variability in growing season rainfall similar to that for total annual rainfall, which has a $60 \%$ coefficient of variation, the standard deviation for growing season rainfall would be $187 \mathrm{~mm}$. Thus one would expect rainfall adequate to maximize yield responses to the $20 \mathrm{~kg} \mathrm{~N}^{-1}$ treatment in at least $70 \%$ of the growing seasons. In this study where the average annual rainfall was $330 \mathrm{~mm}$ (30 mm below the long-term average), yield responses to fertilization were maximum or near maximum in 7 of the 10 years.

In terms of increased forage production and treatment costs, annual applications of $20 \mathrm{~kg} \mathrm{~N}$ ha ${ }^{-1}$ was the most practical fertilizer treatment (Fig. 2). Over the 10-year study, the average annual
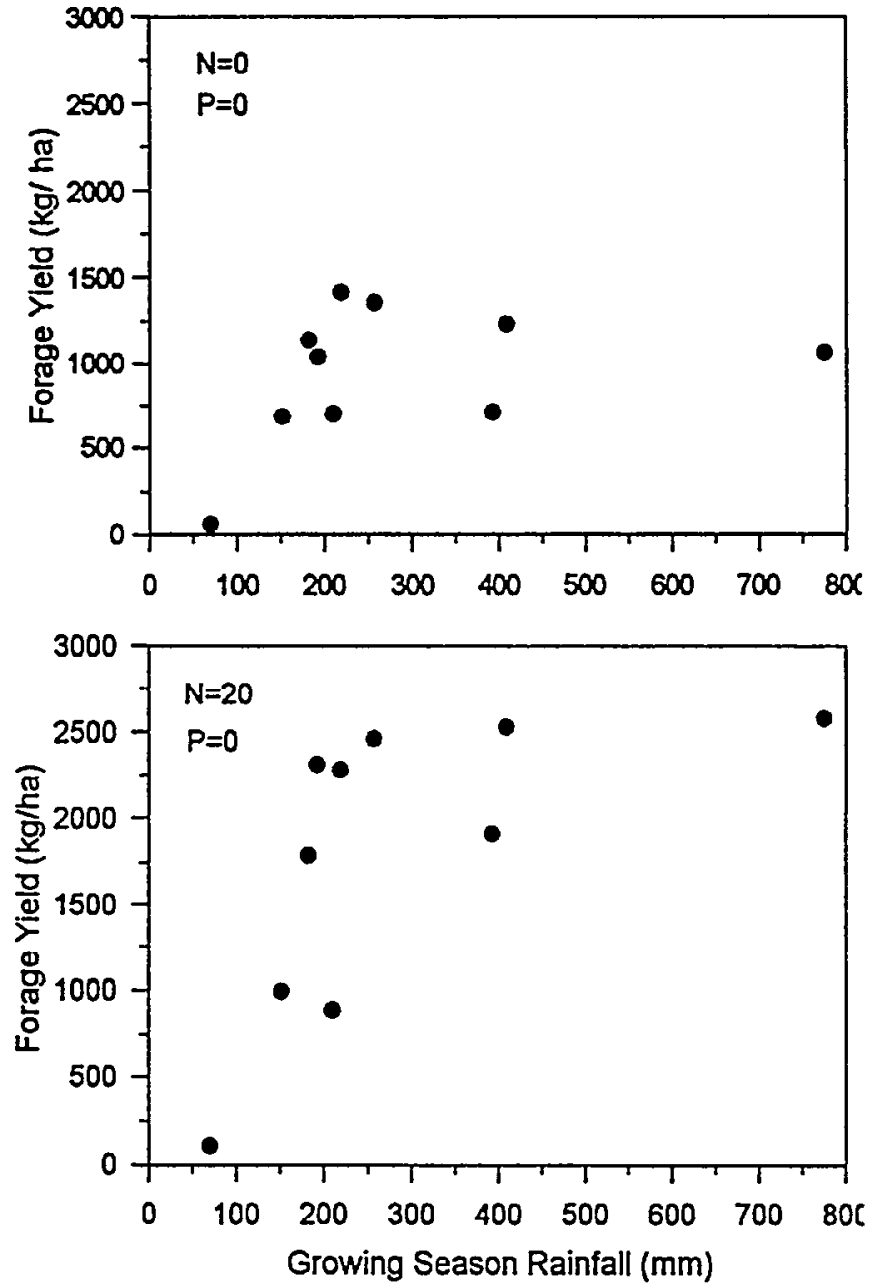

Fig. 3. Relationship of forage yields of $C$. ciliaris to growing season rainfall. Jodhpur, India. 1983-1992.

yield of the $20 \mathrm{~kg} \mathrm{~N}^{-1}$ treatment was $843 \mathrm{~kg} \mathrm{ha}^{-1}$ more than that of the nonfertilized treatment. This translates to a $\mathrm{N}$-use efficiency of $42 \mathrm{~kg}$ of additional forage for every $\mathrm{kg}$ of $\mathrm{N}$ applied. Nitrogen-use efficiency is the units of forage produced per unit of $\mathrm{N}$ applied and is calculated as the difference in forage production between the fertilized (1785 $\mathrm{kg} \mathrm{ha}^{-1}$ for $20 \mathrm{~kg} \mathrm{ha}^{-1} \mathrm{~N}$ treatment) and the nonfertilized ( $\left.942 \mathrm{~kg} \mathrm{ha}^{-1}\right)$ plots. For the 7 high- production years, $\mathrm{N}$-use efficiency was 57 units.

Data from the National Research Council (1970) indicate that a normal growing yearling steer should gain $1 \mathrm{~kg}$ for every $10.5 \mathrm{~kg}$ of forage intake. Using this relationship, the $20-\mathrm{kg} \mathrm{N}^{-1}$ treatment should produce an additional $80 \mathrm{~kg}$ of beef ha-1 or $4 \mathrm{~kg}$ beef $\mathrm{kg}^{-1} \mathrm{~N}$. In the northern Great Plains of America, annual applications of about $40 \mathrm{~kg} \mathrm{~N} \mathrm{ha}^{-1}$ to native range, crested wheatgrass (Agropyron cristatum (L.) Gaertn.) and Russian wildrye (Elymus junceus Fishc.) produced $1.0,1.7$ and $2.2 \mathrm{~kg}$ beef $\mathrm{kg}^{-1} \mathrm{~N}$, respectively (Wight 1976). Information such as this can be used to help make economic evaluations.

This study shows that $C$. ciliaris can perform well even at relatively low levels of rainfall and that annual applications of $20 \mathrm{~kg}$ $\mathrm{N}$ ha ${ }^{-1}$ will more than double forage yields 7 years out of 10 . No economic interpretations have been made, but an $\mathrm{N}$-use efficiency of $42 \mathrm{~kg}$ of forage $\mathrm{kg}^{-1}$ of $\mathrm{N}$ applied suggests that $\mathrm{N}$ fertiliza- 
tion may be a viable option for increasing forage production in this forage-deficient region.

\section{Literature Cited}

Ahuja, L.D. and H.S. Mann. 1975. Rangeland development and management in western Rajasthan. Ann. Arid Zone 14:29-44.

Mutz, J.L. and D. Lynn Drawe. 1983. Clipping frequency and fertilization influence herbage yields and crude protein content of 4 grasses in South Texas. J. Range Manage. 36:582-585.

National Research Council. 1970. Nutrient requirements of beef cattle. Fourth revised edition. Nat. Acad. of Sci., Washington, D.C., 55 p.

Shankarnarayan, K.A. and J.C. Kalla. 1985. Management systems for natural vegetation in arid and semi-arid areas. CAZRI, Jodhpur, $132 \mathrm{p}$.
Shankarnarayan, K.A., G.G.S.N. Rao, and B.V. Ramana Rao. 1985. Grassland productivity and its associative climatic characteristics in western Rajasthan. Trop. Ecol. 26:157-163.

Singh, Mahander and R.K. Aggarwal. 1988. Response to N-fertilization and its sources on the growth and seed production of $C$. ciliaris (L.) in an arid environment, p. 379-381. In: P. Singh, V. Shankar, and A.K. Srivastava (eds.) Abstracts Vol. II, Third Int. Rangeland Congr., Range Manage. Soc. India. New Delhi, India.

Wiedenfeld, R.P., M.T.W. Wooward, and R.R Hoverson. 1985. Forages responses of buffelgrass and 'Pretoria 90' bluestem to nitrogen and phosphorus fertilization in a subtropical climate. J. Range Mange. 38:242-246.

Wight, J. R. 1976. Range fertilization in the northern Great Plains. J. Range Manage. 29:180-185. 